\title{
EXPLORING SIMILARITIES BETWEEN THE GERMAN AND THE DUTCH 'ETHICAL' TRADITIONS: POSSIBILITIES OF THE HISTORY OF RELIGION FOR A THEOLOGICAL APPROACH TO OLD TESTAMENT STUDIES IN SOUth Africa
}

Author:

Jan H. Vorster

\section{Affiliation:}

${ }^{1}$ Department of Systematic Theology and Christian Ethics, University of Pretoria, South Africa

\section{Correspondence to: Jan Vorster}

email:

jan.vorster@pbmr.co.za

\section{Postal address:}

PO Box 14125, Lyttelton

0140, South Africa

\section{Keywords:}

Dialectic theology; history of religion; Rainier

Albertz; Israel's religious

history; early Christianity;

African theological

perspectives

\section{Dates:}

Received: 08 Oct. 2009

Accepted: 17 Feb. 2010

Published: 28 Oct. 2010

How to cite this article:

Vorster, J.H., 2010,

'Exploring similarities

between the German and the Dutch 'ethical' traditions: Possibilities of the history of religion for a theological approach to Old Testament studies in South Africa', HTS Teologiese Studies/ Theological Studies 66(1), Art. \#428, 12 pages. DOI: 10.4102/hts.v66i1.428

This article is available at:

http://www.hts.org.za

Note:

Dr Jan Vorster is a PhD candidate in the Faculty of Theology, University of Pretoria, with Prof.

Dr Johan Buitendag,

Department of Systematic

Theology, as supervisor.

(C) 2010. The Authors. Licensee: OpenJournals

Publishing. This work

is licensed under the

Creative Commons

Attribution License.

\section{ABSTRACT}

This article shows how dialectic theology caused a loss of interest in the history of religion, which was seen as out of touch with the current world. The distinction between theology and the history of religion became increasingly vague. The article focuses on the contribution of Rainier Albertz in his two-volume Religionsgeschichte Israels in alttestamentlicher Zeit (History of Israelite religion in the Old Testament period), 1992. Albertz proposed that the history of religion should be restored to serve as the 'more sensible discipline for abridging the Old Testament'. This article points out several advantages to this approach, namely a different kind of Old Testament theology, starting from current theological problems and searching through the thematic segments of Israel's religious history and that of early Christianity for analogous insights relevant to the problems in question. This article develops the argument that Albertz's suggestions open up possibilities for establishing a vibrant theological environment in South Africa, where theologians from a diverse society can start from different perspectives on current problems, consider the Bible as part of a uniquely defined set of relevant factors and present a kaleidoscope of cross-balancing 'African' theological perspectives. The aim of this approach is to enhance the possibilities of Albertz's suggestions by relating them, in context, to insights from ethical theology in the hope of reviving the debate regarding repositioning the history of religion in a different kind of theological approach. This debate is long in coming: it may already have lost close to 20 years in deserved attention.

\section{INTRODUCTION}

\section{Where two worlds meet}

The practice of Old Testament theology in South Africa creates an interesting environment where scholars from the same historical background but diverse cultures can collaborate.

Being born in Krugersdorp, a few kilometres away from Sharpeville ${ }^{1}$, gives the doctrine of original sin a personal meaning to me. On my birth, a culturally isolated young life began, based as it was on an already established political programme not designed for the freedom of observation and thought. Being brought up within an increasingly unsafe environment, where even faith and church were confirming the status quo, the almost inevitable result was a limited experience of other cultures in my own country due to fear and even hate nurtured on both sides of the political and ethnic spectrum.

It was only much later, when already a student of theology and bringing a brief visit to a theological college at the then University of the North, that I gained some perspective. I was, during 1984, assigned presbytery responsibility for a congregation of the then called 'Reformed Church in Southern Africa' situated in Saulsville. The official name of this church today is the 'Maranatha Reformed Church of Christ'. In conversation with a women's group from that particular congregation (after delivering a sermon interpreted by the pastor loci, the Rev. Jacob Manala (nowadays Professor in Practical Theology at UNISA), my childhood 'surprise' - when the woman working as a domestic in our home talked about the love of God in the same way that my mother did - became part of a completely changed perception of what the religious reality in South Africa really was. Driving to the congregation that morning, through the aggression and hardship of the people in Saulsville, then paradoxically enjoying a warm welcome in the congregation, next realising that the Rev. Manala was, in fact, presenting my sermon with some degree of reinterpretation for the people listening - all this combined in a single experience. Together, it formed an awareness of not only the huge distance emanating from the historical fear, hate and aggression but also, at the same time, a closeness growing from the abundant amount of mutual goodwill present. This awareness convinced me of the power that was alive within the people of South Africa. It was a moment of clarity as I realised that, by the flip of a divine coin, it could have been me born in Sharpeville rather than in Krugersdorp. It could then (on that particular day when the first shots were fired in Sharpeville) have been me viewing the ravine from the opposite side, most probably with much more militant conviction, induced by an opposing programme of cultural indoctrination.

Being proclaimed part of a 'rainbow nation' in 1994 supplied a way of describing the existing diversity and distance almost as a thing of beauty. However, outside the world of faith, this pair of words did

1.On 21 March 1960 at least 180 Black Africans were injured (there are claims of as many as 300) and 69 killed when South African police opened fire on approximately 300 demonstrators, who were protesting against the pass laws, at the township of Sharpeville, near Vereeniging in the Tran at at Langa, a tow. The outside Cape Town, police baton charged and prompted worldwide condemnation of South Africa's Apartheid policies (Boddy-Evans, A., n.d., Sharpeville Massacre, viewed 30 September 2010, from http://africanhistory.about.com/od/apartheid/a/SharpevilleMassacrePt1.htm 
nothing to bridge the gap between red and violet in the new spectrum; neither did the artificial creation of a new shade of pale, intellectual blue-green in between. Obscuring the middle part of the spectrum (in which most of the rainbow's real beauty resides) would be an irrecoverable loss.

I would thus rather opt for a clear statement of background, presuppositions ${ }^{2}$ and intent, rather than trying to be somebody I could never be and, by pretending, merely become an unconvincing creature of circumstance.

\section{PRESUPPOSITIONS}

My introduction to the world of theology came through a faculty ${ }^{4}$ built on a 19th-century model of scientific specialisation (Webster 1994:51), including a good deal of existentialism as packed into dialectic theology (since our study of the New Testament focused almost exclusively on Brunner, Barth and especially Bultmann).

Regarding the discipline of Old Testament theology, the faculty repertoire included a touch of historical-critical results, with a balancing factor from 'ethical' theology ${ }^{5}$ in the ValetonWildeboer-Gemser-Van Selms ${ }^{6}$ tradition. The latter was extolled especially by Professor J.A. Loader (although he was never a member of our faculty) but also by Professor P.M. Venter. 'Ethical' theology holds historical criticism in high esteem, while, at the same time, being committed to a history-of-religion approach, but never loses sight of the fact that truth cannot be known in absolute terms and that faith is always more than only rational. Against this backdrop, a balance between synchronic and diachronic work is skilfully interwoven, as I was taught. Without a conscious decision to do so, I found myself working on the Old Testament in a particular way - almost naturally comfortable with the insights of James Barr and with appreciation for the work of the South African professors in Old Testament Studies, namely J.J. Burden and the late F. Deist.

My introduction to the history of Israelite religion was not an explicit part of the Old Testament-theology curriculum. It was, however, already part of the preceding courses in Hebrew and biblical studies. This was followed by a more formal discipline (or, rather, basket of disciplines) known as Science of Religion

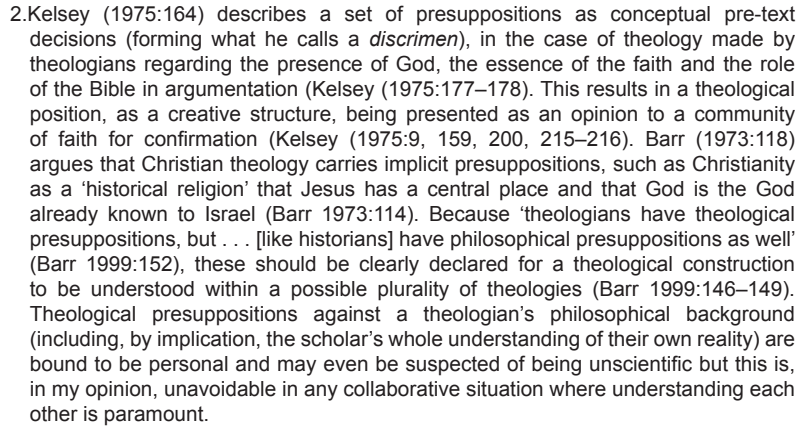

2.Kelsey (1975:164) describes a set of presuppositions as conceptual pre-tex decisions (forming what he calls a discrimen), in the case of theology made by theologians regarding the prose of the Bible in argumentation (Kelsey (1975:177-178). This results in a theologica position, as a creative structure, being presented as an opinion to a community of faith for confirmation (Kelsey (1975:9, 159, 200, 215-216). Barr (1973:118) argues that Christian theology carries implicit presuppositions, such as Christianity as a 'historical religion' that Jesus has a central place and that God is the God already known to Israel (Barr 1973:114). Because 'theologians have theological presuppositions, but ... [like historians] have philosophical presuppositions as well (Barr 1999:152), these should be clearly declared for a theological construction to be understood within a possible plurality of theologies (Barr 1999:146-149). Theological prespositions against a theologian's philophical backround Theological presuppositions against a theologian's philosophical background (including, by implication, he scholar's whole understanding of their own reality) are 列 in my opinion, unavoidable in any collaborative situation where understanding each other is paramount.

3.See the tale of 'the hare with artificial horns' in Masenya (2004:456-458)

4.Faculty of Theology (Section A), University of Pretoria, South Africa.

5.Ethical traditions refers to the ethical movement (discussed in more detail later in this article). In this context, the term 'ethical' is not to be understood as meaning 'moral' but rather, as Loader (1984:1) explains, '[that the truth revealed by God is ethical, means that it is aimed at the heart and not in the first instance at the rational faculty of humans' (my translation). Loader refers to the description supplied in 1904 faculty of humans' (my translation). Loader refers to the description supplied in 1904
by J.J.P. Valeton Jr (in his work Etisch, as published in Nijmegen) 'Dat de door God by J.J.P. Valeton Jr (in his work Etisch, as published in Nijmegen) 'Dat de door God
geopenbaarde waarheid etisch is, wil zeggen dat zij zich richt tot het hart en niet in de eerste plaats tot het verstand van den mensch

6.See Loader (1984:212), where he accords a high value to the specialist work of the Dutch ethical theologians and states that this line of theological thought (that of Valeton-Wildeboer-Gemser-Van Selms) could be revived in the future.

7.Both were directly or indirectly students of Gemser's and Van Selms's. Even when Venter became interested in the possible meaning of the canon, traces of the ethical approach were always visible in his research. and Missiology, which was presented without so much as a trace of the suspicion that the history of religion may be philosophical and therefore inappropriate to theology (as presupposed by dialectic theology). Part of this discipline was an introduction to the wider world of religious phenomenology, with regular incursions into what was deemed relevant for theology. ${ }^{8}$ In hindsight, a major restrictive factor was the overwhelmingly theoretical approach to Science of Religion, which limited practical interaction with Black African theology to the bare minimum. This, however, was understandable due to the stranglehold of orthodox views on theological roots, combined with the power of church politics exerted mainly through a then politically highly biased Department of Church History.

Some aspects of my disposition as stated here are implied by the introductory paragraph and the background information given earlier:

- I am a Christian, formed by Western theology and philosophy.

- I believe that God is the God already known to Israel.

- I respect the results of historical-critical research from the viewpoint of 'ethical' theology, not allowing for modernist rationalism or orthodox positivism.

- I am convinced that absolute truth (as the positivistic dream of absolute objectivity) is humanly unattainable and I therefore accept it in mythical terms. This, however, does not result in relativism but rather in perspectivism. As a result, an honest statement of background and theological presuppositions (discrimen), as shown later in this article and as required by early 'ethical' theology (described later) and done here, is critical in order to understand any theological construct.

- I think that the validity of theological constructs is not so much a matter of right or wrong but that it should rather be tested against the Bible as a classical model or norm for theology in its function as a document of faith and against its results in the modern community of the faithful.

- I am sure that (and I base this on history and experience) most people born in Africa, including myself (born as a White male in South Africa), share surprising goodwill in search of solutions that unify.

- The religions of Israel and Christianity are historical religions and should therefore be susceptible to a history-ofreligion approach

\section{OLD TESTAMENT THEOLOGY IN SOUTH AFRICA}

Masenya (2004:455-469) offered an example ${ }^{9}$ of an 'African' (Black South African female or Bosadi ${ }^{10}$ ) perspective. In her opinion, the study of Old Testament theology in South Africa today is experienced as being out of touch with reality (Masenya 1997:459). This verdict is based on her conviction that theological education in South Africa is held captive by a Western colonial view through Western-orientated professors with the capacity

8.A comparison to the situation described by Albertz at most theological faculties in Germany after World War I regarding the Religionsgeschichte Israels no longer being a standard subject (completely replaced by lectures on die Theologie des Alten Testaments or pushed aside as a special subject) can, at most, be limited in my case due to the definite ethical influences on my induction into Old Testament theology. Howere present, the decline of interest in the history of Israelite religion theology. However present, the decline of interion triumphant progress of dialectic theology (Albertz 1992:18), did not have the same type of impact on my introductory environment.

9.Masenya wrote more than the two articles referenced here. Without intending to ridicule Masenya, the discussion is limited to the two referenced articles in order to establish, by example, a starting point in the argument representing the current state of the Black South African perspective on the study of the Old Testament. Although these limited examples may not fully represent the viewpoints of Masenya, I am convinced that they supply a fair representation of the inner contractions built into

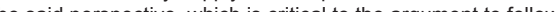

10.See Masenya (1997:439-447) for a substantiation of this 'approach' (which I would prefer to call a 'perspective') 
to alienate 'Africans' from their cultural heritage (Masenya 1997:455). Given the angle of her perspective on the common socio-political context shared by all people born in South African, Masenya's drive for self-recovery and self-affirmation is obvious and understandable. Having been introduced to theology through biblical studies at a historically Black university and having been lectured by White male professors without reference to the African context (generalised as that of the modern readers) made her feel spiritually deprived and 'contextually empty' (Masenya 1997:458). It was a reaction to her frustration that led to her taking this contradictory stance. On the one hand, however, Masenya shows deep gratitude towards the likes of Professor Jasper J. Burden for leading her through the dark on the way to respect for herself and her own cultural heritage. On the other hand (in what she herself described as 'ironic'), she still regards the Western theological heritage at work behind the empowering encouragement of her professors (the works of European theological giants such as Rudolf Bultmann, Karl Barth, Dietrich Bonhoeffe) as totally irrelevant to the African context (Masenya 1997:459). Amplifying the contradiction, Masenya uses the Western theological method of historical analysis (Masenya 1997:464) as the basis for a socio-political interpretation of Proverbs 6:6-11 (Masenya 1997:464-469), while using Northern Sotho proverbs (Masenya 1997:466-467) to produce a Black 'African-South African' reading of the text (Masenya 1997:456). However condensed and almost casual, this ambivalence of driving out the devil with Beelzebub is what Masenya actually does. Although conscious of her background, Masenya does not clearly state her discrimen. It is therefore hardly surprising that no trace of sensitivity for her own approach as a mixture of influences (from 'African-South African' perspectives and Western theology and methods) can be detected. Despite her generalisations and contradictory statements, however, Masenya's (1997:459) clear articulation of the problem still facing Old Testament theology in South Africa should not be underestimated or ignored:

Our theology thrives on sophisticated arguments which have scarcely any bearing on the daily lives of the people. . . Studies about the Bible should not only end in the past of the biblical text; these studies must address the whole African person in his/her totality: politically, spiritually, economically, socially, et cetera, because... there are no such compartmentalisations in the African view of things.

(Masenya 2004:459)

If Masenya is representative of how Old Testament theology is experienced, then theology in South Africa, specifically the study of the Old Testament, is certainly in need of:

- an approach linking the results of theological study to the daily lives and problems of real people

- an unifying approach to bridge the gap among different cultures originating in the same historical setting but from different or partially different roots.

\section{A TIME TO CHANGE}

Albertz interpreted the time when his two-volume magnum opus, Religionsgeschichte Israels in alttestamentlicher Zeit (History of Israelite religion in the Old Testament period), was published as Umbruchzeit, that is the time of the shifting of paradigms (Albertz 1992:6). He presented his wish to re-evaluate the discipline of the history of Israelite religion within the range of Old Testament disciplines as the end of a long process of personal reflection and stimulating developments in theological history at the end of the 20th century. The history of Israelite religion had been pushed to the sidelines since World War I, due mainly to impulses from dialectic theology. Within dialectic theology, religion and the revelation of God had become opposing phenomena, the former made out to be human, part of human culture and humanity's self-assertion or defences against God (Barr 1999:107); outspoken suspicion had been created against philosophy and anything that smelt of it, including the study of religion. Barth's assertion was even that religion is the concentrated manifestation of human unbelief ('der konzentrierte Ausdruck des menschlichen Unglaubens' KD I, 2, 303). What was left of 'the history of Israelite religion' had been incorporated into Old Testament theology in such a way that the distinction between the two had become extremely vague. Although Rendtorff (1995:35-36) later claimed that he never questioned the independence of Old Testament theology over and against the 'history of Israelite religion' and that he therefore failed to comprehend the drive to eliminate one or the other, it is still clear that Albertz was decisively influenced by Rendtorff's early remarks in 1963 that the distinction between theology and the history of religion had practically ceased to exist and that trying to separate the one from the other would no longer make any sense (see Albertz's direct quotation of Rendtorff [1963] 1995:150-151 in Albertz 1992:37). Convinced that the attempt by Schmid $t^{11}$ to integrate Old Testament theology and the history of Israelite religion was practically impossible, Albertz took a radical stance by suggesting that the history of Israelite religion was a worthy replacement for Old Testament theology. He was convinced that the history of Israelite religion had again become a meaningful and theologically significant task at the end of the 20th century (Albertz 1992:19).

\section{THE HISTORY OF RESEARCH}

Albertz (1992:20-30) based his suppositions and suggestions on his perspective of the history of the research of Israelite religion. Since Gabler, the historical investigation of biblical statements (interpretatio) had been seen as only a preliminary stage to philosophical reflection on the religious concepts (comparatio) used in theology. The true ideas basic to dogmatic reflection had been much more philosophical than historical and Albertz was convinced that Gabler's programme did not lead to a real historical account of Old Testament religion. The idea of religion could be recognised only in its numerous impure historical appearances. Along this line of thought, De Wette attempted to strip particularism from religious symbols in order to reveal their inner core as timeless and universal. The pure form of religion was to be found with Moses and in the Psalms. The pre-exilic period was classified as Hebraism (a matter of life and enthusiasm), while the post-exilic period was negatively classified as Judaism (a matter of concepts and literalism).

The first real historical account of the religion of Israel was Vatke's Religion des Alten Testaments (1835). In a philosophicalhistorical approach, he destroyed the idea that the whole of Israel's religion was fully developed in the early Mosaic period. He saw Moses as a prophetically gifted nomadic leader and part of a dialectic process in which the absolute Spirit revealed itself to the human spirit. Vatke made use of Hegel's philosophy of history and logical structure (thesis-antithesis-synthesis). Dividing the history of Israelite religion into pre-prophetic (thesis), prophetic (antithesis) and post-prophetic (synthesis) periods, he could evaluate the post-exilic era much more positively. Theocracy transposed from particularistic legalism to universalised wisdom and internalised religious poetry. Vatke's highly complicated philosophical approach, however, did not find much following.

According to Albertz (1992:23), the next significant move was made by Wellhausen two generations later. Steering clear of a philosophical approach, Wellhausen explained the history of religion as an organic process of interplay between political history and religious views. Vatke's somewhat 'bloodless' design ('etwas "blutleere" Aufriß') came to life with Wellhausen in a multifaceted course of history filled with conflict and change. Wellhausen never produced an extended history of Israel's religion. His pupils, however, did. Of these, Albertz regarded the elder Smend's Lehrbuch der alttestamentlichen Religionsgeschichte (first published in 1893) as the most important. Keeping to Wellhausen's threefold scheme (the popular or national religion

11.Schmidt, W.H., 1968, Alttestamentliche Glaube in seiner Geschichte. Zur Geschichte des alttestamentlichen Gottesverständnis, Kirchenern Verlag, Neukirchen-Vluyn. 
of ancient Israel, the prophetic religion and the Jewish religion), Smend returned to De Wette's distinction between Hebraism and Judaism. He did, however, interpret Judaism (and Christianity) as a positive result, where the prophetic religion individualised and universalised the popular or national religion of ancient Israel. For Albertz, Smend's contribution was valuable because he provided a real historical summary of Old Testament scholarship rather than a traditional biblical theology in the guise of a history-of-religion title.

From the history-of-religions school, Gunkel's Schöpfung und Chaos in Urzeit und Endzeit (1895) included the positive usage of material from oriental cultures through the tracing of possible influences from the Babylonian creation myths, which added a comparative element to the study of Israelite religion. Albertz (1992:26) thinks that the development of approach reached a level of maturity, where a history of religion (including both Old and New Testaments) providing a sound historical basis for dogmatic reflection was within reach.

In Germany, however, World War I caused a radical collapse in the study of the history of religion. When the war was over, another approach (known as 'dialectic theology', the theology of crisis or the theology of the Word) came into being. There was then a need for revelation and absolute values, not catered for in the relativism perceived to be built into the history-of-religions method. In his Israelitisch-jüdische Religionsgeschichte und alttestamentliche Theologie published in 1926, Eißfeldt attempted to rescue the history-of-religions research of the Old Testament by assigning different methodological approaches to the two disciplines. In this compromise, the history of religions could focus on the knowledge of Old Testament religion as a historical entity being relative and immanent, while Old Testament theology could be concerned with faith grasped by the Absolute and Transcendent. The history-of-religions approach, however, was effectively paralysed and no progress was made until after World War II.

The first external impulse for the revival of the history-ofreligions approach in Germany came from Sweden, where the rejection of this approach never quite gained a foothold. Ringgren's Israelite religion (1963) focused on the period of the monarchy but again followed the familiar dogmatic ordering derived from Old Testament theologies from the time. The writings of the prophets landed up alongside cult and king (the 'official religion'). In Ringgren's work, Albertz found no trace of Wellhausen's organic process of interplay between political history and religious views. The genetic understanding of a multifaceted course of history filled with conflict and change had been fossilised in an abstract intellectual system.

Albertz appreciated the useful wealth of material in Schmidt's Alttestamentlicher Glaube in seiner Umwelt (1968) but detected a lack of sufficient attention to the exilic and post-exilic period. Schmidt had limited himself to what was of interest to Christians and had focused on the nature and history of the Old Testament understanding of God. He had not sought to depict the history of Israelite religion as a whole. Although limited by a theological approach based on the premise that the essence of a religion is encapsulated in its understanding of God, however, Schmidt's account still represented progress by taking influences from the ancient Near East (including influences from Ugarit) into account.

The last contribution highlighted by Albertz is the Geschichte der israelitischen Religion published by Fohrer in 1969. This work centres on Israel's religious development in correlation with its political and social history in comparison with neighbouring religions. Fohrer, for example, described the historical consequences of the encounter between Israel's nomadic clan religion and the settled Canaanite religion. The driving force behind the development of Israel's religion was not derived from without but from four specific inner-Israelite impulses, namely
Mosaic religion, kingship, prophecy and Deuteronomistic theology. Albertz was concerned that this theory of impulses could become a socially detached history of ideas. He had the same concern about Fohrer's concept of Daseinshaltung (existential attitude). Fohrer distinguished six existential attitudes conservative, magical, cultic, national-religious, sapiential and prophetic - that, according to him, could give an accurate account of the different currents of faith in Israelite religion. When these Daseinshaltungen are associated with a static set of universalised ideas, it could cause an inadequate understanding of the interplay between social development and the religion of Israel (because the inner theological conflicts and embedded social interaction are not described).

\section{A DIFFERENT KIND OF OLD TESTAMENT THEOLOGY}

The history of research presented Albertz with specific theological problems and concerns. These concerns reappear in his formulation of the requirements for a revived historyof-religion approach. At the same time, he stated his discrimen clearly. As a result, his argument matches this clarity.

A history of Israelite religion must, according to Albertz's (1992:3032) conviction, comply with several requirements if it is to be the better option. He listed seven criteria, some intended to correct limitations created by previous research, others to develop positive trends already present from the same environment. I propose to expand this list with two additional suppositions, both derived from his own comparison of the history of religion with Old Testament theology. The first seven requirements are the following:

1. A history of Israelite religion must be a pure historical construct without any hidden ordering through dogmatic principles (this in response to Ringgren and Schmidt).

2. A history of Israelite religion must be an inclusive process leaving room for both Judaism and Christianity by avoiding any attempts to force history into later Christian evaluations, divisions and devaluations (in response to certain aspects in the work of De Wette, Wellhausen and Smend).

3. A history of Israelite religion must embrace all aspects of historical development (political, social, religious and cultic) as reflected in the written reports of how people experienced God (a positive development of a principle already present in the work of Wellhausen and Smend).

4. A history of Israelite religion must investigate the role played by all economic, social and political vehicles of social change (the individual, family, community and state) and correlating altered religious statements and schemes (a development of Wellhausen's appreciation of social and political influences on religion).

5. A history of Israelite religion must defrost the 'frozen dialogue' in the Old Testament tradition as an ongoing discussion among different groups about the challenges of interpreting and reacting to particular historical events in the light of God's will (the first steps in this direction were taken by Vatke).

6. A history of Israelite religion must compare the Israelite patterns of interpretation and conduct fairly and without apologetic constraint with similar social and religious complexes in its ancient Near Eastern environment, not to demonstrate uniqueness but to enhance our understanding of Israel's religion (again, in response to Wellhausen and dialectic theology).

7. A history of Israelite religion must appropriately counter the traditional Christian anti-Judaistic overemphasis of the preexilic and exilic periods by, as far as possible, devoting equal attention to the decisiveness of the post-exilic period in the formation of the religion of Israel (in response to Vatke, Wellhausen and Schmidt). 
A clear method is to be defined if the task of the history of religion is to meet these requirements. To define the task and method, Albertz (1992:32-38) compared Eißfeldt's definitions of both the history of religion and Old Testament theology. For Eißfeldt, the history of religion is a historical discipline objectively describing an entity claiming to be the revelation or word of God, therefore being 'truth' with absolute value. Albertz opposed this idea of a presuppositionless historiography. He argued that a historian of religion can never reach complete objectivity. Being a member of a religious community involved in internal and external controversies over how to cope with human problems, the historian can never escape being bound to her or his own reality and theological interests. To the extent that a historian is (and wishes to remain) a theologian, therefore, the historian's struggle over appropriate responses and decisions about God are inevitably significant for the present. The history of Israelite religion today is thus clearly more theological than Eißfeldt thought.

Old Testament theology, according to Eißfeldt's definition, however, is a systematic-theological and normative discipline aimed at the needs of modern religious communities. It has the character of witness and is valid or true only in the circle of faith within which it is proclaimed. It therefore cannot have the form of a historical description and can, by nature, only be described systematically. Developments in the intermittent decades have made it clear that this task and method could not be maintained. Those clinging to a dogmatic approach (like Childs, who defined Old Testament theology as a specifically Christian discipline) have nevertheless survived until today. ${ }^{12}$ By contrast, Albertz argued that theological proclamation are exclusively historically orientated. Making cross-sections through historically defined religion, Old Testament theology intends to illuminate the inner structure and characteristics of faith. While suspecting that an integrating theoretical system does lie behind religion, Old Testament theology focuses on finding a theological centre or a complex of notions to serve this purpose. This quest has shown no convincing result other than the recognition that Israel's world of thought cannot be divorced from her world of history. Old Testament theology had therefore clearly become more historical than Eißfeldt had thought.

From this, I derive two suppositions to be added to the seven requirements listed previously. Although somewhat obscured by Albertz's comparison, these observations on the history of religion becoming more theological and theology becoming more historical have a definite impact on the rest of his argument and deserve to be noted here:

- A history of Israelite religion - being written by a living historian - cannot escape having significance for present theological problems (Albertz 1992:33-34); it must be linked to the present to be theologically relevant. ${ }^{13}$

12.Albertz associated Vriezen with Childs. Although arguments may be presented to show some traces of an ethical approach. Vriezen can more easily be associated show some associated with the so-caled 'confesson failed to give any account of on ethical theologians). I suspect that, considering Vriezen's environment, this may have resulted in Albertz finding some definite support rather than opposition in Dutch theology.

13.As emphasised by Barr (1999:119), this supposition was already implicit earlier when Albertz (1978:1-2) motivated his distinction between individual and collective religion in Israel, starting from a problem created through a public statement by the German Kaiser prior to World War I claiming God to be on the side of the Cermen army (he Gëtem Warl). Ged was 'with Vatem war). God was 'wih them'- yet stl two wars we sost. Albertz therefore proceeded to search the history of Israelite religion for relevant experiences. The results of his research showed that promises (such as Ps 23:4 and Is 41:10) were aimed at supporting the individual, even in times when the larger group or nation experienced the exact opposite. The history of Israel's religion showed that individual and collective levels should not be confused ('Illegitim werden sie erst, wenn man diese unbedingte Vertrauensbeziehung aus ihrem Lebensbereich löst und sie in den Lebensbereich einer großen Gruppe von Menschen überträgt'). The problem of two wars lost despite the Kaiser's premise can be explained in this way through the history of Israelite religion and the distinction between the individual and the collective, (1005.200) added to this Alberz's outs dialogue with Judaism following Auschwitz. The history of Israelite religion was determined by (and should therefore be relevant to) a current theological question.
- A history of Israelite religion must allow, in some way, for historically orientated theological perspectives.

With the boundaries between the history of religion and Old Testament theology broken down, Albertz reached the logical conclusion: that the history of Israelite religion became the 'more sensible discipline for abridging the Old Testament'. The reasons again amount to a perfect seven. The history of Israelite religion:

1. corresponds better to the largely historical structure of the Old Testament

2. shows more respect for the insight that religious statements and their historical background are inseparably interlinked

3. is less compelled to level out variety and contradictions in religious statements through intellectual abstraction

4. has greater potential to bring the dialogue about theological clarification, demarcation and consensus frozen in the Old Testament back to life to correspond with present-day theological interaction

5. sees its continuation in the people of Israel (with whom Christian churches can relate) rather than in any religious ideas

6. openly, under eschatological conditions, dispenses with any claim to absolute truth in a multi-religious world

7. is open to comparison with other convictions and therefore to promoting dialogue with other religions.

Albertz thus called for a strict history-of-religion approach. His initial plea was for a more or less complete abandonment of Old Testament theology (Barr 1999:117). According to this radical stance, mixtures of history and theology are required to be avoided; no compromises to accommodate theology are to be made. With (or, rather, within) the history of religion as the overall perspective, a theological perspective may exist (which starts from current theological problems, searching through the thematic sections of Israel's and early Christianity's religious history for analogous insights relevant to the problems in question). In this way, the history of religion takes the place of Old Testament theology. Beyond doubt, Albertz's suggestion represented at least a different kind of Old Testament theology from that which was customary up to then in the Euro-American tradition.

In reality, Albertz mildly softened his radical stance, formulating his intention clearly as early as 1992 . He did not wish to sound the 'Abgesang' (funeral dirge) for Old Testament theology (Albertz 1992:37) but was convinced that, given a fair chance alongside Old Testament theology, the discipline of the historyof-Israelite religion would prove itself as the more suitable method with which to abridge the Old Testament. For much too long, Old Testament theology had disregarded the results of the historical-critical method by forcing the cultic and institutional basis of the Old Testament into the background. Twentiethcentury theologies did not capture enough of the dynamic religious life and vibrant theological interaction of Israel's religion. As a result, these theologies often became 'extremely stiff, lifeless and sometimes also boring' (1995a:12). Keeping Old Testament theology alive only on emotional grounds alongside a second subject called 'history of Israelite religion' was, in Albertz's (1995a:24) view, simply an unaffordable luxury in an environment already hampered by a shortage of resources. Despite the provocative title of his article (Hat die Theologie des Alten Testaments doch noch eine Chance?) published in 1995, however, he did not stress the point further. Instead, he used this article to formulate a more accommodating realism. Answering some of his critics and supporters, he stated the impression that his thesis was being understood to be more fundamental than he had meant it to be. It had not been his intention to have the subject of Old Testament theology replaced by another branch of academic instruction by the name of 'history of religion'. His plea was rather for a clear reorientation in the established research tradition. No Old Testament scholar was to lose her or his job but the whole system of the discipline and the methods of the history of religion were to overhaul and even replace ${ }^{14}$ those of Old Testament theology (Ailbertz 1995b:177). 


\section{Reaction to Rainier Albertz}

The initial suggestion by Albertz drew a good deal of attention. In 1995, a complete edition of the Jahrbuch für biblische Theologie 10, containing papers read at the meeting of the Society of Biblical Literature held in Leuven during 1994, was devoted to Albertz's ideas. Reaction from the contributing scholars varied from enthusiasm (by, for example, Lemche [1995]) to the censure that Albertz presented a false alternative for Old Testament theology (by, for example, Crüsemann [1995]). The summary provided here is a selection to illustrate that Albertz's ideas are taken seriously, even by the unconvinced.

\section{NOT CONVINCED}

\section{Frank Crúsemann}

Quite comfortable with the high value that Albertz assigned to religio-historical work, Crüsemann still had difficulties with the thesis that the history of Israel's religion in Old Testament times and Old Testament theology could be seen as alternatives. He felt that neither of the two, on their own, could do justice to the theological quality of Scripture (Crüsemann 1995:69-70); Albertz's proposal did not sufficiently consider the distance between the time of narration (Erzählzeit) and the earlier, more obscure time narrated (erzählte Zeit). Crüsemann argued that the form and content of the canon do not allow either a pure diachronic nor a pure synchronic approach. If either the erzählte Zeit or the Erzählzeit becomes dominant, too much of importance is lost. Both history of religion and Old Testament theology have the same difficulties with the contents of texts and the concomitant conflicting socio-political environments (Crüsemann 1995:71-74). Both are equally limited in their ability to understand texts historically and to grasp the totality of the religious experience to which they testify. Any given alternative, whether systematic or text-orientated, descriptive or normative, partial or holistic, can therefore present only part of the bigger picture (Crüsemann 1995:75). Crűsemann was clear: Albertz suggested an inadequate alternative (Crüsemann 1995:72).

\section{Theo Sundermeier}

Although no Old Testament scholar, Sundermeier proceeded to classify Albertz from the perspective of the discipline of the science of religion with (of all things) dialectic theology, since he differentiated so strictly between theology and Religionswissenschaft (Sundermeier 1995:200, 203). Several aspects of Albertz's approach (such as a clear declaration of presuppositions, a willingness to compare with other religions and an acknowledgment of external and inner influences) do indeed fit this model exactly. One trait of this model absent from the work of Albertz (probably in reaction to dialectic theology), however, is the use of phenomenology, which is normally used as a bridge to the theological summary of the particular religion being described (Sundermeier 1995:203-204). Albertz did not convince him that the history of Israelite religion could sufficiently cater for theological needs only when correlated with current issues by the historian. Sundermeier therefore concluded that, without phenomenology, Albertz had painted himself into a corner. History of religion and theology are the inseparable sides of a single coin, two overlapping ellipses with the same focal point. From the perspective of the history of religion, Albertz's suggestion represented a misleading alternative. Keeping only the history of Israelite religion (even in Albertz's definition) alive would mean that the overall summary provided by theology remains lacking (Sundermeier 1995:205-206).

\section{PARTIALLY CONVINCED}

\section{John Barton}

Respectfully sympathetic to Albertz's arguments, Barton was convinced that Old Testament theology as a discipline should be maintained. He concurred with Albertz in that the first goal of scholarly theology should be to work historically and descriptively, even though such description could never be a pure, factual, positivistic collection of data, since it would always include the element of interpretation (Barton 1995:29). The history of the Israelite religion, however, cannot fully replace Old Testament theology. The main reason for Barton's opposition is the vacuum created by Albertz's suggestion between JewishChristian theology and text. This interstice (Zwischenraum) should be (and, in reality, is) filled with the dialectic tension created by, on the one hand, theological systems derived from the text and, on the other hand, the text itself. Barton described this environment as 'Old Testament theology'. Within this environment, derived systems and terminology can be applied retroactively in the interpretation of the text (Barton 1995:34). Without this interstice, where derived concepts that would not necessarily have been understood by old Israel can be used, Old Testament research would become isolated from dialogue with systematic theology and other Bible research.

\section{James Barr}

Barr shared the viewpoint with Albertz that we are being thrown back to the problems presented by the theology of the 19th century, mainly as a result of dialectic theology. In obvious appreciation of the emphatically historical approach (Barr 1999:118-120), he viewed Albertz's enthusiastic commendations as highly stimulating and forming a good corrective to the thoughts of biblical theologians with negative attitudes towards the history of religion. Acknowledging Albertz's positive statement of principle and his convincing style, Barr stated, 'in his enthusiasm he underestimates the importance and potential biblical theology, even of a somewhat traditional kind, continues to have' (Barr 1999:123). Barr, however, wanted the history of religion to be accorded full recognition and importance by biblical theology. History of religion and theology cannot be separated and the latter must recognise the material and positive theological importance of the former's results. Taking the social and socio-political contexts of Old Testament text seriously adds to the historical validity of Old Testament theology. Differences in scope and interest still justify the recognition of both the history of religion and theology as separate but overlapping disciplines (Barr 1999:138-139). Albertz's model supplies protection against the naive conception of actualisation to be achieved through the simple transfer of the biblical message to the present day. Albertz suggested to 'begin with the present day, then consider the Bible, not alone, but as part of the mixture of relevant factors, including the traditions which historically connected us back to the Bible' ${ }^{15}$ Barr stressed that more is to be said for this common-sense view, which people may still be experiencing as venturesome or tentative.

\section{CONVINCED}

\section{Niels Lemche}

Representative of a smaller school of research calling for a new paradigm in Old Testament scholarship (Lemche 1995:79-80), Lemche welcomed Albertz's contribution. Old Testament theology, in Lemche's view, cannot be counted as an exact science. Indeed, theology is studied as part of the humanities, which produces no facts with logical or scientific proof but rather produces conjectures and unfounded theories almost as though these are virtues (he called this activity 'intellektueller Zeitvertrieb' [intellectual pastime]) (Lemche 1995:83-84). Lemche would obviously associate with Albertz in rejecting traditional Old Testament theology and therefore stated that he found Albertz's conclusions completely acceptable (Lemche 1995:85). He especially appreciated the more scientific potential of Albertz's model, interpreting it in support of his own distinction

\footnotetext{
15.Barr $(1973: 126,127,132)$ seems to combine Albertz's model with his own wellargued view on 'ongoing tradition' and inspiration. The Bible grew out of tradition argued view on 'ongoing tradition' and inspiration. The Bible grew out of tradition
and tradition followed the fixing of a canon. 'Post-biblical tradition' fills the gap and tradition followed the fixing of a canon. 'Post-biblical
between now and then and should also be taken seriously.
} 
of 'three Israels' (historical Israel, biblical Israel and ancient Israel, the last of which exists only in the fantasies of scholars) (Lemche 1995:81). Convinced that the Old Testament is a Hellenistic document supplying very little (if any) grounds for a reconstruction of the religion of ancient Israel, only the religion of the Jews in Hellenistic times can be identified (Lemche 1995:86). The unhistorical, normative, absolute and seemingly only diachronic objectives of Old Testament theology could be better served by the real diachronic study of the history of mentality (Mentalitätsgeschichte) in the time when the Old Testament was formed. He classified Albertz's proposal as an important part of historical reconstruction from the viewpoint of a Mentalitätsgeschichte (Lemche 1995:92).

\section{Concluding thoughts on Rainier Albertz}

The overwhelming consensus of most reactions to Albertz's suggestion is that the history of Israelite religion cannot satisfactorily replace Old Testament theology. Both should be maintained as separate but overlapping disciplines, although the history of religion should be accorded full recognition.

At the end of this initial debate, Albertz reformulated his viewpoints in light of the results. Jahrbuch für biblische Theologie 10 included the paper that he first delivered at the 1993 meeting of the Society of Biblical Literature in Münster (Albertz 1995a:3-24). His simple plea for a clear reorientation in the ongoing history of research ('eine klare forschungsgeschichliche Umorientierung') was indeed part of this paper's subtitle. It may be possible to argue that he was simply wondering why the history of Israelite religion (with so many theoretical, methodological and conceptual advantages) had not surpassed Old Testament theology long ago and that he was not, in the first instance, focusing on replacing Old Testament theology in search of a new basis for the history of Israelite religion (Albertz 1995a:16; 'zur Begründung einer neuen Religionsgeschichte Israels'). Albertz (1995b:177) could then claim, as in his Abschließende Stellungnahme at the end of the 1994 meeting, to have been misunderstood. ${ }^{16}$ For those then misled by the passion of Albertz's argumentation, however, some extenuating circumstances do exist. It is sometimes precisely the extreme statements formulated in the heat of an argument that later become a stimulus in a reader's mind and creativity, explaining the wide range of reactions to Albertz's ideas. Quite interesting is that, after Rendtorff claimed to be misunderstood by Albertz (Rendtorff 1995:35-36), Albertz did the same. Even though a train of misunderstandings should result in chaos, Albertz's ideas still triggered wide-ranging discussion with the potential of supplying the basis for a fresh, sensible, inclusive and exciting theological approach.

\section{A CONCURRENT TRADITION ('ETHICAL' THEOLOGY)}

The Dutch 'ethical' movement reached its apex under the leadership of the Old Testament scholars Josué Jean Philippe Valeton Jr (1848-1912) and Gerrit Wildeboer (1855-1911). This movement played an important role in saving the historicalcritical study of the Bible in the Netherlands, taking a position between liberal modernism on the one hand and orthodox opponents on the other.

Modernism wanted to ensure a standing for rationalism in Christianity (Loader 1984:164). Revelation was denied in favour of a rational approach and Scripture was studied as a purely rational undertaking of objective criticism. Critical results were assigned absolute value. Kuenen took the lead in Dutch modernism by publishing the two volumes of his De Godsdienst van Israël in 1869 and 1870 .

The orthodox end of the spectrum rejected any form of the critical method as an instrument opposed to revelation. Based

16.This was not accepted by Lohfink (1995:207), who did not appreciate Albertz accusing him of playing 'Fächerpoker' (the political positioning of sub-disciplines within a faculty of learning). The only good thing, according to Lohfink, coming from within a faculty of learning). The only good thing, according to Lohfink, coming from
Albertz was that he had triggered a rather interesting debate (Lohfink 1995:230). on a strict biblicism, it encompassed spokespersons of several conservative groups in the Netherlands. The beginning of this divide in Dutch theology is usually taken as 1823, when Isaäc da Costa published his Beswaren tegen de geest van de eeuw (Loader 1984:169).

'Ethical' theology was the third option that developed between modernism and conservatism. Also known as a form of 'Vermittlungs' theology (a middle position based on compromises between the extremes), its exponents never tried to synthesise modernism and conservatism into one harmonious whole. Instead, they involved themselves deliberately in the identification of problems within the disciplines of Old Testament scholarship (Loader 1984:191) and, in the process, consciously created an independent option, not so much a movement as a theological environment where groups existed both to their left and to their right.

The Dutch 'ethical' movement is still, to a large extent, ignored by the German and English-speaking theological traditions, probably because most of the relevant works were written in Dutch. Only three of Valeton's articles were published in the Zeitschrift für die alltestamentliche Wissenschaft during 1892 and 1893 and a single 'ethical' classic (Wildeboer's Het ontstaan van den Kanon des Ouden Verbonds, published in 1889) was translated into English in 1895, surviving through four editions until 1908 (Loader 1984:115). Most of the remainder ${ }^{17}$ of the classical 'ethical' works still await revived interest in Dutch libraries, predominantly in the university libraries of Groningen and Utrecht. Despite its influence on Old Testament theology in South Africa (summarised below), the 'ethical' movement is also underutilised in South Africa; literally, no classical work from this line of thought is available for study. ${ }^{18}$ Covering a movement of this importance in a few paragraphs cannot reverse this so easily. A few observations, however, may hopefully result in generating some interest in a very marked influence on our shared South African theological background. To my knowledge, this movement has not received appropriate attention and acknowledgement, with the exception of the work by Loader, who made a start in this direction with his historical analysis.

\section{Josué Jean Philippe Valeton Jr}

Only 29 years of age, J.J.P. Valeton Jr was appointed professor of the history of Israelite religion at the University of Utrecht in 1877. In his publications, Valeton focused mainly on the history

17. Wildeboer's commentaries, especially on the wisdom books, did make him known in the German-speaking world (Loader 1984:96). It does seem, however, as if the main achievements of the ethical movement were not taken note of. It may also be that the principles behind ethical theology and the background behind the theologians working from this perspective were not known or properly understood. An example of this is Albertz (1992:34-35) referencing an isolated sentence by Vriezen on revelation in the Old Testament, placing him with the much more orthodox Childs in one line. Following the link from Vriezen to Van der Woude orthodox Childs in one ine. Following the link from Vrezen to Van der Woude would be more well-known work Geschriften (Vriezen \& Van der Woude [1948]1976). Had he placed Vriezen in context, Albertz may have been led to the discovery of an already existing practical application of the essence of his own suggestion in ethical theology, which linked religio-historical and theological perspectives where appropriate.

18.Works by the original ethical theologians are difficult to find. The University of Pretoria library, for example, has only a single meditation written by Valeton. This makes an understanding of the ethical movement or its local influence well-nigh maks an impossible my own sumbork however, has limited reader potentlal because it was witten in Af kaans. Much of this dissertation has also been published through other means: HTS Teologiese Studies/Theological Studies 41 (Loader 1985a:233-251) on Valeton as a historian of religion (Afrikaans); Old Testament Essays 3 (Loader 1985b18-32) on the ethical concept of revelation (English); Oud Testamentaise Werkgemeenschap in Suid-Afrika 27/28 (Loader 1986:148-166) on Wildeboer's isagogic contribution (Afrikaans); HTS Teologiese Studies/Theological Studies 43 (Loader 1987:47-56) and Gesammelte studien (Loader 2001) on the ethical concept of truth (Afrikaans and German): Journal for Semitics 7 (Loader 1995.240-250) on the contribution and German). Jounal for Semilics 7 (Loader 1995.240-250) on the contribution of Van Selms, HTS Teologiese Studies/Theological Studies 42 (Loader 1996:124) article (Afrikaans); Festschrift für Otto Kaiser (Loader 2004a:1037-1051) on the relationship with God as a central idea in ethical theology (German). 
of religion and exegesis. He rejected the modernist conviction representing truth and revelation as abstract ideas to be accessed only rationally; he also rejected the orthodox reliance on an abstract set of dogmas seen to have priority over life itself (Valeton 1898:14).

First and foremost, Valeton considered the revelation of God as aimed not at rational reception but rather at the human heart. Revelation is to be experienced as a religious experience of and in life (Valeton 1898:18). This experience is subsequently expressed in human terms, which, as an expression, is open to historical-critical study. The experience cannot be equalled to a propositional truth or doctrine and cannot be absolutised, since it is accessible relative to its own expression in human terms. A fortiori, human expression (studied critically) can never be an absolute truth because it is relative to religious experience (1898:19). Theology should therefore focus on the spiritual things in life as revealed by God. The point of departure should not be an abstract construct but rather that point where a theological utterance relates to life.

Thus an inner correlation between pure historical, critical and scholarly work on the one hand and theology on the other is given.

Science and faith are interactive (Valeton 1898:25). There is no neutral or objective science and no neutral or objective experience of revelation (Valeton 1898:20). It is only in a reciprocal relationship (Valeton 1898:25) to each other, in the moment of contact that is the interface, where one-sidedness and differences can be identified and conquered and where both positions can be appreciated (Loader 1984:22; Valeton 1898:2324).

A neutral position is nowhere to be found and presuppositions should therefore be clearly formulated. The same object viewed from different angles results in different views and perspectives. This observation underscores that Valeton cannot be classified as a relativist but fits better into a description such as 'perspectivism'. Stating his own suppositions (Loader 1984:22-23; Valeton 1898:7-25), Valeton allowed us a clear view of his approach:

- Theology is Christian theology.

- All theology presupposes God.

- Just as the existence of matter cannot be proven in natural science and must be assumed, so the existence of God cannot be proven in theology, which places faith and assumption on the same level.

- A relationship exists between the human spirit and 'things that cannot be seen', of which human beings become aware through revelation.

- Theology cannot be practised without a link to a specific social situation or social dimension.

Valeton held several other equally important views: the community of faith is a safeguard against subjectivism (Valeton 1898:28); the Bible is not the Word of God but contains it (Valeton 1898:33); the Bible is the basic source for judging religious statements (Valeton 1898:35) and not all biblical books (such as those containing 'ethical' norms from ancient times and cultures) can be assigned the same value (Valeton 1898:40). These views show remarkable similarities with insights formulated by Barr (1973:117-118) and Kelsey (1975:205-216).

Valeton (1898:48-51) wrote two major works on the history of religion. In the first (Bijdragen tot de Kennis en de Waardering van den Israëlitischen Godsdienst I en II, in the journal Studiën 7, 1-27 and 81-120, respectively), published in 1881, he did not describe Israelite religion chronologically. Instead, he typified it by arguing the change of polytheism to monotheism as early as the 8th century BCE. He was of the opinion that Israel's religion could be understood only when related to the religious systems, cults and ethics of other Semitic religions. 'ethical' views on the relation between God and humanity are evident in this work, where Valeton described revelation as comprehensible manifestations and inspiration as God's help to understand those manifestations. In his second major work on the history of religion (Die Israeliten, in De la Saussaye's Lehrbuch der Religionsgeschichte), published in 1897, Valeton divided the history of Israelite religion into four periods (the pre-monarchic period, the monarchy before Jehu, the time following Jehu and the Greek period) but still used two doctrines (the doctrine of Yahweh and the doctrine of the land) as ordering principles within each period (Valeton 1898:52-56). Following these major works, Valeton published three phenomenological essays (on the Israelite name for God, the books of the old covenant and the word torah). These contributions to the study of Israelite religion were based on and integrated with Valeton's literary studies, which ranged from some work on the prophets Joel and Hosea to contributions on the study of the Pentateuch and even a popular commentary on the Psalms (Valeton 1898:61-79). Based on thorough research of the text, with attention to detail and scrupulous argumentation (Valeton 1898:65), Valeton was able to create an integrated working environment where critical scholarship and theology could cooperate closely.

\section{Gerrit Wildeboer}

During 1884, on the recommendation of Kuenen, Wildeboer took over as professor of Old Testament theology from J.J.P. Valeton Sr (father of J.J.P. Valeton Jr) in Groningen. The modernist Kuenen convinced Wildeboer of the validity of the historicalcritical approach, although Wildeboer never became a follower of his. Instead, Wildeboer opted to continue the ecclesiastical and social commitments as minister of religion prior to 1884 . In theology, he worked in step with Valeton to establish the 'ethical' approach. While Valeton focused on the principles underlying 'ethical' theology, Wildeboer systematically ordered and explained historical-critical results and their application within the 'ethical' approach (Loader 1984:92-96). Wildeboer did not like to be called a 'Vermittlungs' theologian and was adamant that 'ethical' theology represented an independent third option and that it should be judged in terms of its own perspectives (Loader 1984:102).

Wildeboer saw revelation as a dynamic event in life, which meant that it participated in history. To illustrate this, he used a history-of-religion approach as early as 1884 for a phenomenological monograph on Jewish festivals. This work included the first signs of what was developed four years later by Gunkel in Göttingen with his idea of Sitz-im-Leben (Loader 1984:99; Wildeboer 1884:70-91). During 1886, in a debate with Kuenen on the evolutionary principle, he made an important distinction. On the one hand, he described scientific knowledge as 'a totally uncommitted task' having nothing to do with theological insights. On the other hand, knowledge of faith includes theological evaluation and, like biblical texts, cannot be forced into unsuitable scholarly schemes. God cannot be fitted into concepts or propositions but is revealed in real life on a personal level (Loader 1984:99-100; Wildeboer 1886 [1897]:53-54). Theological reflection does not, however, add to the meaning by an author of a biblical text but works with an inner-textual snapshot in time taken of a stream of tradition. It is like analysing a painting: you can analyse either the canvas (that is, do a scientific historical analysis) or the genius of the artist (that is, the theological meaning). Wildeboer opposed orthodox dogmatism by showing that it relied on convictions about the Bible rather than on the Bible itself, while the 'ethicals' based their ideas on exegetical results Loader 1984:103). Opposing the modernists was a bit more difficult because Wildeboer appreciated the critical method used to uncover the history of Israelite religion (Loader 1984:106). He did, however, keep to the characteristic ethical principle of revelation having to be experienced before it can be understood (Loader 1984:104), thus leaving room for a non-rational element in theology (Loader 1984:103). 
Concerning the history of Israelite religion, Wildeboer, without hesitation, declared his belief that God also revealed himself to other nations, falling back on the patristic idea of the logos spermatikos (Loader 1984:104-105). This explains his lively interest in the Amarna letters, the 'Babel-Bible controversy' and the archaeological findings in Palestine (Loader 1984:118119). Apart from this, he made a distinction between 'begotten religion' (geworde godsdiens) and 'started/established religion' (gestigte godsdiens). The first he explained as a type of natural religion and the second as religion based on revelation. The first did not develop into the second but was a change-over on the impulse of revelation (Loader 1984:111). Based on this distinction, he divided the religion of Israel into two parts: the ancient religion of the nation; and Yahwism as the revealed religion (Loader 1984:120).

Wildeboer's social compassion also showed in his representation of the Sitz-im-Leben behind Old Testament texts. This compassion flowed over into the needs of his own Sitz-im-Leben when he summarised the historical-critical results of his time in a way accessible to both professional scholars and the broader public, allowing many to accept the value of the critical approach (Loader 1084:127).

\section{The difference between the 'ethical' approach and the German tradition}

As far as our topic is concerned, there is effectively only one dissimilarity. When the German tradition (due to the impact of dialectic theology) marginalised the history of religion, ethical theology did not redirect with it. The result was that the effect of dialectic theology in this regard was not as dramatic. Insights gleaned from dialectic theology were not ignored in the later ethical tradition but the balanced approach allowing critical methods to integrate with theology was maintained.

\section{'Ethical' theology in South Africa}

The principles and methods developed by Valeton and Wildeboer influenced their pupils and associates extensively. Ethical theology developed in an approach that can be said to have linked Dutch theologians during the 20th century when, after World War I, there was hardly a discernible movement or association such as the modernists and the orthodox groups had. It does not lie within the scope of this article to supply a complete description of how ethical theology manifested in Dutch Old Testament scholarship (see Loader 1984:136-202 for a fuller description) and I therefore focus on those who had a direct influence on Old Testament scholarship in South Africa.

Two well-known scholars introduced the 'ethical' approach to South Africa. The first main figure was Gemser, who was a student of Böhl's (an Assyriologist with leanings towards ethical theology) and of Bleeker's (an Old Testament scholar who specialised in the history of religion). In 1926, Gemser was appointed to the then Transvaalse Universiteits Kollege (TUK) in Pretoria to teach Semitic languages and the Old Testament; long after the TUK became the University of Pretoria, he returned to Groningen as successor to Bleeker and Vriezen. The other main figure was Van Selms. He came from the same theological tradition, being a student of Obbink's (another ethical who specialised in the history of religion) and of Böhl's. In 1938, he was appointed to teach Semitic languages and Old Testament theology at the University of Pretoria, where he stayed until his retirement in 1971. By this time, Van der Woude had already succeeded Gemser in Groningen.

Both Gemser and Van Selms directly influenced the study of the Old Testament in South Africa. Outside of the Nederduitsch Hervormde Kerk, Gemser's influence was spread through the journal Hervormde teologiese studies, where he served as editor. Van Selms focused on the Old Testament Society of South Africa (OTSSA) and had an influence discernible to the present day; in fact, there was a Van Selms memorial lecture on the first evening of the 2005 OTSSA congress. What should not only be remembered but also be retained are the characteristics associated with the approaches by Gemser and Van Selms: an incisive critical sense; a historical-critical approach to the Old Testament; the upholding of revelation as an important category in theology; aversion to dogmatism; a genuine devoutness; and ecclesiastical commitment (see Loader 1984:211).

The influence of 'ethical' theology also came through other means. The commentary series Tekst en uitleg, started between World Wars I and II, kept the typical ethical approach to Old Testament studies alive. When redefined after World War II, the name of the series was changed and it was decided to start afresh, rewriting the commentaries in a new format. The process was managed by Van Selms and Van der Woude (Groningen). The first commentaries in the new series (De prediking van het Oude Testament) were published in 1967. Even today, many of these commentaries are to be found on the bookshelves of pastors (especially those working in the Nederduitsch Hervormde Kerk) who completed their studies at the University of Pretoria. The list of contributors to this series includes, apart from Gemser and Van Selms, other prominent South African Old Testament scholars, such as Fensham, Van Zyl (who could not, however, be called an 'ethical') and Loader (a student of both Van Selms's and Van der Woude's, who certainly can be called an ethical). The series of commentaries was accompanied by a New Testament counterpart, widely in use in South Africa (De prediking van het Nieuwe Testament) and successively under the editorship of Koopmans, Van Stempvoort and Klijn (professor of the New Testament at the Rijksuniversiteit Groningen and close colleague of Van der Woude's).

This development highlights another characteristic of the 'ethical' approach. I call it attunement, like the strumming of a chord on a perfectly tuned guitar (the strings representing the different theological disciplines and the instrument representing the equilibrium between science and theology, all blended together harmoniously). Ethical theology has this effect. Working on the Old Testament in the sphere of the ethical approach allows movement between sub-disciplines with natural ease to produce a holistic theological result, including perspectives from other disciplines, such as systematic theology, phenomenology and New Testament exegesis. This tradition can produce theologians (of which some may specialise in a sub-discipline) working with theology as an integrated whole.

\section{An 'ethical' perspective on the way forward}

More than two decades ago, Loader (1984:212) stated his expectation that the Valeton-Wildeboer-Gemser-Van Selms line of thought would be the direction of the future. This could mean more but, in fact, adumbrated that which Albertz had suggested eight years later.

\section{A confluence of approach}

In biology, the term 'convergent evolution' describes the phenomenon of species adapting from different taxonomic (biologically classified) groups towards similar forms and characteristics. Fish in the oceans surrounding Antarctica, for example, are specially adapted to survive the cold; it was discovered in the 1960s that these species evolved a type of antifreeze to do so. The antifreeze is composed of glycoproteins circulating in the bloodstream, with the function of slightly lowering the freezing temperature of bodily fluids. As ice crystals form, the glycoproteins surround and isolate them. Without this glycoprotein composite, the fish would freeze and die. It seems almost too clever to be true. Nature has nevertheless achieved this in more than simply this one case: the fish around the Arctic pole (on the opposite side of earth), for example, also have antifreeze proteins. Although the two types of fish had no connection apart from both being fish, they independently developed antifreeze 
genes and proteins. Moreover, these genes (having the same functional results) differ between north and south. It seems that nature, where there is a finite number of effective solutions to the same challenges, responds independently in similar fashion. What happened to the German and Dutch theological approaches can also be explained through this term. ${ }^{19}$

An example showing that a confluence of approach has already taken place in South African Old Testament theology can be seen in the way that Le Roux described his or our historical heritage. In his 1993 monograph, Le Roux acknowledged scholars forming the history of Old Testament theology in South Africa during the past 30 years. His enthusiasm confirms that a historian can never reach complete objectivity and cannot be other than involved (Albertz 1992:34). Being part of the history that he described, Le Roux also supplied a perspective on the influences that he experienced himself. Among many others, the following names (with ethical theological backgrounds) appear prominently: Loader (Le Roux 1993:28-32, 300-331), Fensham (1970:114-140, 272), ${ }^{20}$ Van Selms (174-189, 342-348), Venter (332) and Bezuidenhout (342-348). ${ }^{21}$ No wonder that, when Le Roux later (in 1997) stated his view on our historical heritage, he could start with Gabler (Le Roux 1997:402-412), then focus on the immense impact of the 19th century, tiptoe through the pitfalls of dialectic theology like an ethical theologian par excellence, drawing attention to Eißfeldt and Eichrodt, and, in the end, state the following as part of his conclusions (with reference to Albertz):

Religionsgeschichte' must once again occupy a major position in the curriculum as well as in the endeavours of the Old Testament scholar. . . It can lie open . . the living context in which Israel's theology (theologies?) took shape . . . narrating real lifeexperiences of human beings. [Note the ethical influence] . . Perhaps a theology of the Old Testament will accomplish more if it redefines itself in terms of history and establish a firmer link with 'Religionsgeschichte'.

(Le Roux 1997:420)

This is nothing short of the realising of Loader's 1984 prediction and, at the same time, is in line with the 1995 results of the discussion triggered by Albertz in 1992.

\section{Possibilities of the history of religion for an approach to Old Testament studies in South Africa}

Where two theological approaches reach the same conclusion independently, there must be something to the result. Old Testament theology must be held in high esteem. It contains too much of great value simply to be pushed aside, in spite of all the justified concerns as to its style and presentation. Old Testament scholarship cannot make do with any limitation on theological reflection. Although it cannot be replaced by the history of Israelite religion, however, Albertz, on his own, supplied enough motivation for the history of religion to be allowed a

19.It may be argued at this point that the term 'convergent evolution' (although describing a fairly wide-spread phenomenon in nature) is not sufficiently proven in the natural sciences and should therefore not be used. This argument, however, does not nullify the point made here. Irrespective of scientific proof in the natural sciences, the meaning of this term matches an observation made on the development of theological thinking, especially in South Africa. It concurs to the point where the observation made here may also be in need of further study for sufficient proof. The need for further study and proof should not bar the observation from being made.

20.I include Fensham in my list of 'ethical' influences only because he is one of the few South Africans allowed to publish in the series De prediking van de Oude Testament, where his commentary on Exodus was published in 1970 alongside the work of others, the bulk of which can definitely be described as ethical. In this commentary, however, Fensham supplied a textual explanation but did not explicitly focus on the current theological meaning of the text (which is a characteristic of the ethical approach).

21.I include Venter and Bezuidenhoudt as part of the ethical tradition because they were both trained in the same tradition as Van Selms and Loader and approach, as I do (almost by default), the Old Testament in this way, even without conscious decision in this regard. more important role. Both Albertz and most of his critics agreed that a new balance between the history of Israelite religion and Old Testament theology is to be pursued, something that ethical theology had already proven to be a feasible option. Revelation aims at the hearts and minds of people, making history and theology two sides of the same coin.

Can two approaches be combined into one? It has already happened. When Le Roux walked through history, ending with Albertz, the influences and characteristics from the ethical perspective were already recognisable (albeit implicit) in the way that he described his own background and reached his conclusions.

Can it happen again? Considering the current need in South African Old Testament scholarship for an approach linking the results of theological study to the daily lives and problems of real people, unifying scholars with different roots and from different cultures and theological traditions (although with different perspectives on the problems facing us at this point), I cannot see any reason why it could or should not happen again. It is possible simply to sit back and wait another 100 years. Then it may even happen on its own - as suspected in nature when there are but a finite number of effective solutions to the same challenges. Alternatively, we can meet the challenge as it presents itself in present-day South Africa.

Valeton, Albertz, Barr, Kelsey and Sundermeier all stressed the usefulness and importance of stating presuppositions in terms of a discrimen. Clarity on background and pre-text decisions enhance understanding. Moving from understanding to respect is but a small step. Moreover, a clearly stated discrimen reduces the risk of unfair interpretation and supplies grounds for both constructive criticism and possible agreement. Considering and accepting who and where we are (Africans living at a particular point in history), the playing field can be levelled by setting up an environment conducive to creativity.

As early as Valeton and as late as Albertz, we are provided with many possible contours that such a discrimen can take. By simply stating these, I suspect that the level of understanding and even mutual agreement could increase by default. There would, for example, be very little room for disagreement if the assumption that God exists were made a point of departure. The same would hold true, I think, for the relativity-of-truth claims, the limitations of objectivity, convictions about the subjectivity of religious perspectives or the relationship between faith and the reality of human experience. Any clarification on the level of importance assigned to revelation, any statement about the relationship between history and theology, any honest attempt to steer away from division and devaluation, in short, any declaration aimed at inclusive theological reflection could have a similar effect. Analysing Old Testament religion within its historical context should inevitably strive to uncover the underlying political economic, social, religious and cultic aspects of the embedded cultural diversity in Israel and its environment. Just as inevitable would be relevance for our current theological problems. My plea is therefore not to avoid but, on the contrary, to make explicit judgments about the relevance of biblical theologies to current vehicles of theological and social change. Discrimen particulars of this kind should be stated in a way that enhances understanding and respect. If we can establish some level of respect in stated beliefs and convictions, if we let each other in on the analysis of our own identities, histories and forms of religion, then an exciting freedom of expression can develop, based on the understanding that we all form part of a highly interesting hybrid of theological traditions and approaches.

Putting ourselves through some historical criticism could produce useful results. A history-of-religion approach, when applied to ourselves and our own situation, would free us from the everpresent fear of losing our own identity. When applied in our search for perspectives relevant to current problems in multiple traditions connecting us back to the Old Testament, a historyof-religion approach could be equally useful. Gerstenberger ([2001]2002:1-2) pointed out that the Old Testament, in itself, 
does not offer a unitary theology or ethic. As 'an extraordinary stroke of good fortune', the Old Testament is rather, in his view, a conglomerate of faithful experiences emanating from very different historical and social situations, containing fragmentary (sometimes heavily edited or manipulated) time-conditioned testimonies representing a diversity of theologies fused together at a later stage. Originally distinct religious systems were reconciled on the basis of elements common to them all. The historical-critical study of biblical texts, where the history of Israelite religion forms the bridge to a summary of the contained theology, still fits this picture perfectly.

Imagine what could be achieved if all African theologians (especially those born and bred in South Africa, irrespective of cultural background, including myself, therefore) truly managed to break free of the state of mind (characterised by hate and prejudice) that they were born into and that they were (like it or not) culturally programmed to accept as the only way to survive. Relieved of this constraint, it could become possible to start investing the energy so gained into the analysis of the theological problems and needs of our own time by illuminating the value of different perspectives on our own Sitz-im-Leben. Proceeding to uncover the treasure of theological and philosophical insight hidden in the diverse traditions connecting us to the Bible, we could even end up truly utilising the theological variety embedded in the Old Testament. If we could only allow the Old Testament to save us from the urge to evaluate theologies in terms of 'right' or 'wrong', we could start listening to theologies growing out of our own Sitz-imLeben and appreciate them like different 'symphonies' (Loader 2004b:252-266). As 'an extraordinary stroke of good fortune', we are presented with the opportunity to construct a respectful way of including the variety in our cultural heritage (from the African-South African, to an Afrikaans-Protestant-South African and, it is to be hoped, to a somewhat modern perspective like my own) in a compendium of African theologies.

When South Africa was in the throes of dramatic change, the Soweto String Quartet ${ }^{22}$ performed at the presidential inauguration of Nelson Mandela in 1994 and, in doing so, gained worldwide recognition in the promotion of African music. Sandile Khemese (2005), first violinist and musical director of this outstanding group, remarked as follows in an interview:

I was aware of our traditional music, but I didn't realize that I could express it through the violin. I thought it was an exclusively European instrument. When... I realized that we could arrange African music for strings - it was a revelation.

(Khemese 2005)

Listening to the song Sikelela (which includes the lyrics 'Nkosi Sikele' $i$-Africa', meaning 'God bless Africa') as recorded on the Soweto String Quartet's album Renaissance, I realised that it is possible to play a true African song of unity and reconciliation on a traditionally exclusive European instrument - and what a thing of beauty it is. I am convinced that something similar can be brought about in South African Old Testament theology. The strings (a critical history-of-Israelite-religion approach) on an African Stradivarius (an Old Testament theology in touch with South African reality) played by any Old Testament theologian with but half of Khemese's insight - this holds the potential of producing a beautiful sound, as never before heard, of a broken country on the road to healing.

\section{REFERENCES}

Albertz, R., 1978, Persönliche Frommigkeit und Offizielle Religion - Religionsinterner Pluralismus in Israel und Babilon [Personal piety and official religion: Religious pluralism in Israel and Babylon], Calwer Verlag, Stuttgart.

Albertz, R., 1992, Religionsgeschichte Israels in alttestamentlicher Zeit, Vandenhoeck \& Ruprecht, Göttingen. (English translation: A history of Israelite religion in the Old Testament period, 2 vols., John Knox Press, Louisville, CT, 1994).

22.The Soweto String Quartet consists of three Khemese brothers (Sandile, Thami and Reuben) and their friend Makhosini Mnguni.
Albertz, R., 1995a, 'Religionsgeschichte Israels statt Theologie des Alten Testaments - Plädoyer für eine forschungsgeschichtliche Umorientierung [Religious history of Israel instead of Theology of the Old Testament - plea for a reseach-historical reorientation]', in Jahrbuch für biblische Theologie 10, Manfred Siegel, Neukirchen-Vluyn.

Albertz, R., 1995b, 'Hat die Theologie des Alten Testaments doch noch eine Chance - Abschließende Stellungnahme in Leuven [Does the theology of the Old Testament still have a chance - Final opinion in Leuven]', in Jahrbuch für biblische Theologie 10, Manfred Siegel, Neukirchen-Vluyn.

Barr, J., 1973, The Bible in the modern world, SCM, Suffolk.

Barr, J., 1999, The concept of biblical theology - An Old Testament perspective, Fortress Press, Minneapolis.

Barton, J., 1995, 'Alt Testamentliche Theologie nach Albertz [Old Testament Theology by Albertz]', in Jahrbuch für biblische Theologie 10, Manfred Siegel, Neukirchen-Vluyn.

Crüsemann, F., 1995, 'Religionsgeschichte oder Theologie des Alten Testaments? Elementäre Úberlegungen $\mathrm{zu}$ einer falsche Alternative [Religious history and theology of the The Old Testament? Elementary considerations to a false choice]', in Jahrbuch für biblische Theologie 10, Manfred Siegel, Neukirchen-Vluyn.

Deist, F., 2 1984, A concise dictionary of theological terms, JL van Schaik, Pretoria.

De la Saussaye, C., 1897, Lehrbuch der Religionsgeschichte [Manual of religious history], Mohr, Freiburg/Leipzig.

De Vaux, R., 1973, Hoe het oude Israel leefde [How Ancient Israel lived], deel 1 \& 2, tweede druk, vertl. L. Grollenburg, Romen \& Zonen.

Fensham, F.C., 1970, Exodus, Callenbach, Nijkerk.

Gerstenberger, E.S., [2001] 2002, Theologies in the Old Testament, transl. J. Bowden, T \& T Clark, London/New York.

Janowski, B. \& Lohfink, N. (Hrsg.), 1995, Jahrbuch für biblische Theologi [Yearbook for biblical theology], 10, Manfred Siegel, Neukirchen-Vluyn.

Kelsey, D.H., 1975, The uses of Scripture in recent theology, SCM, London.

Khemese, S., 2005, 'Statement made in an interview with Maranatha and published in Jam Ally Entertainment SA's Biography of the Soweto String Quartet', viewed 30 September 2010, from http://www.jamally.co.za/ssq.htm

Lemche, N., 1995, 'Warum die Theologie des Alten Testaments einen Irrweg darstellt [Why is the theology of the Old Testament representing a wrong path]', in Jahrbuch für biblische Theologie, 10, Manfred Siegel, Neukirchen-Vluyn.

Le Roux, J.H., 1993, A story of two ways - Thirty years of Old Testament scholarship in South Africa, Old Testament Essays, suppl. 2, Verba Vitae, Pretoria.

Le Roux, J.H., 1997, 'Our historical heritage', Old Testament Essays 10(3), 401-423.

Loader, J.A., 1984, 'Die etiese Ou-Testamentici in Nederland tussen 1870 en 1914 [The ethical Old Testament scholars in the Netherlands between 1870 and 1914]', ongepubliseerde proefskrif, Departement Kerk Geskiedenis, Universiteit van Suid-Afrika.

Loader, J.A., 1985a, ‘J J P Valeton as godsdienshistorikus [J.J.P. as religious historian]', HTS Teologiese Studies/Theological Studies 41, 233-251.

Loader, J.A., 1985b, 'The concept of revelation in Dutch ethical theology: Its implications for Old Testament scholarship', Old Testament Essays 3, 18-32.

Loader, J.A., 1986, ‘Die bydrae van Gerrit Wildeboer (18551911) tot die $\mathrm{Ou}$ Testamentiese inleidingswetenskap [The contribution of Gerrit Wildeboer (1855-1911) to Old Testament Sciences]', Oud Testamentaise Werkgemeenschap in Suid-Afrika 27/28, 148-166.

Loader, J.A., 1987, 'Tertium datur - Oor die etiese waarheidsbegrip [Tertium datur - the true ethical understanding]', HTS Teologiese Studies/Theological Studies 43, 47-56.

Loader, J.A., 1995, 'Adrianus van Selms: Responsum', Journal for Semitics 7, 240-250. 
Loader, J.A., 1996, "n Hervormde tradisie as heelmiddel [Reformed tradition as a healing aid]', HTS Teologiese Studies/ Theological Studies, 42, 1-24.

Loader, J.A., 2001, Begegnung mit Gott: Gesammelte Studien im Bereich des Alten Testaments [Encounter with God: Collected studies in the area of the Old Testament], Wiener Alttestamentliche Studien 3, Peter Lang, Wien.

Loader, J.A., 2004a, 'Begegnung mit Gott als Zentralbegriff der niederländischen Etischen Theologie [Encounter with God as the central concept of Dutch Ethical Theology]', in M. Witte (Hrsg.), Gott und Mensch im Dialog. Festschrift für Otto Kaiser zum 80. Geburtstag, n.p., De Gruyter, Berlin.

Loader, J.A., 2004b, 'Theologies as symphonies', Old Testament Essays 17(2), 252-266.

Lohfink, N., 1995, 'Fächerpoker und Theologie [Political positioning and Theology]', in Jahrbuch für biblische Theologie, 10, Manfred Siegel, Neukirchen-Vluyn.

Masenya, M., 1997, 'Redefining ourselves: A Bosadi (womanhood) approach', Old Testament Essays 10(3), 439-447.

Masenya, M., 2004, 'Teaching Western-orientated Old Testament studies to African students: An exercise in wisdom or folly', Old Testament Essays 17(3), 455-469.

Rendtorff, R., 1995, 'Die Hermeneutik einer kanonische Theologie des Alten Testaments. Prolegomena [To interpret the canonical theology of the Old Testament. Prolegomena]', in Jahrbuch für biblische Theologie, 10, Manfred Siegel, Neukirchen-Vluyn.
Sundermeier, T., 1995, 'Religionswissenschaft versus Theologie? Zur Verhältnisbestimmung von Religionswissenschaft und Theologie aus religionswissenschaftlicher Sicht [Religion versus theology? For the relation of religion and science, Theology from a religious scientific point of view]', in Jahrbuch für biblische Theologie 10, Manfred Siegel, Neukirchen-Vluyn.

Valeton, J.J.P., 1898, De veronderstelling der theologie [The assumption of Theology], Van Druten, Utrecht.

Vriezen, T.B.C. \& Van der Woude, A.S., [1948] 1976, De literatuur van Oud-Israël [The literature of Ancient Israel], 5th edn., Servire/Wassenaar, Utrecht.

Webster, J., 1994, 'The new dialogue between physics and theology: A traveller's guide', in C.W. Du Toit (ed.), Theology and the new physics, n.p., Institute for Theological Research, Unisa, Pretoria.

Wildeboer, G., 1884, 'De Joodse feesten als historische gedenkdagen, een getuigenis voor den voortgang der openbaring onder Israël [The Jewish festivals as historical memorial days, a testimony to the progress of revelation in Israell', in Karakter en beginselen van het historisch-kritisch ondersoek des Ouden Verbonds, SWV 21, n.p.

Wildeboer, G., [1886] 1897, 'Het historisch-kritisch ondersoek des Ouden Verbonds en de Evolutieleer [The historicalcritical investigation to the Old Covenant and Evolution]', pp. 45-69, SWV 21, n.p. 